\title{
Phytoprotection
}

\section{Transgenic Bacillus thuringiensis}

\section{James A. Baum}

Volume 79, numéro 4, 1998

OECD Workshop - Sustainable Pest Management, Safe Utilization of New Organisms in Biological Control. Montréal, Québec, Canada. September 27-30, 1998.

Atelier de l'OCDE - Gestion durable des ennemis des cultures,

Utilisation sécuritaire de nouveaux organismes de lutte biologique.

Montréal, Québec, Canada. 27-30 Septembre 1998.

URI : https://id.erudit.org/iderudit/706170ar

DOI : https://doi.org/10.7202/706170ar

Aller au sommaire du numéro

Éditeur(s)

Société de protection des plantes du Québec (SPPQ)l

ISSN

0031-9511 (imprimé)

1710-1603 (numérique)

Découvrir la revue

Citer cet article

Baum, J. A. (1998). Transgenic Bacillus thuringiensis. Phytoprotection, 79(4),

127-130. https://doi.org/10.7202/706170ar d'utilisation que vous pouvez consulter en ligne.

https://apropos.erudit.org/fr/usagers/politique-dutilisation/ 


\title{
Transgenic Bacillus thuringiensis
}

\author{
James A. Baum \\ Ecogen Inc. Langhorne, PA, USA
}

\section{INTRODUCTION}

Bacillus thuringiensis $(B t)$ continues to be the world's most successful biological pesticide. Currently, there are over 200 Bt-based bioinsecticide products registered with the U.S. Environmental Protection Agency for the control of lepidopteran, dipteran, and coleopteran pests. While the vast majority of these registrations are for naturally occurring Bts, transconjugant Bts and $B$ ts modified by recombinant DNA technology have been registered as active ingredients.

As a source of genes for insecticidal proteins, $B$. thuringiensis has no peer. Corporate, institutional, and government strain collections of $B$. thuringiensis contain thousands of strain isolates from around the world. The rapid growth in the number of new insecticidal crystal protein (cry) genes reported in the scientific and patent literature over the past several years, due largely to the gene discovery programs of companies involved in Bt bioinsecticide and transgenic plant development, has prompted the adoption of a new nomenclature system that categorizes the encoded Cry proteins on the basis of amino acid sequence identity rather than on insecticidal activity (1). The Cry proteins of $B$. thuringiensis, also referred to as $\delta$-endotoxins, comprise a diverse group of insecticidal agents. Presently, there are $\sim 80$ different classes/subclasses of Cry proteins, representing at least four distinct protein families that have apparently co-evolved toxicity towards insects. The rapid pace of Cry protein discovery can be followed by visiting the $B t$ gene nomenclature home page at the following URL: http: //www.biols.susx.ac.uk/Home/ Neil_Crickmore/Bt/.

This remarkable diversity of insecticidal traits has fueled research and development programs to engineer insectresistant plants expressing modified cry genes. Although the commercial introduction of transgenic crops such as cotton and corn in the U.S. has eroded, to some extent, the market for foliarapplied $B t$ bioinsecticides, the row crop markets have never been a major market for these insecticides. In agriculture, $B t$ bioinsecticides continue to be important in vegetable and tree fruit and nut markets and as tools for integrated pest management.

\section{OPPORTUNITIES FOR IMPROVING B. THURINGIENSIS BIOINSECTICIDES}

The mode of action of $B$. thuringiensis as an insecticide is recognized to be complex, involving the contribution of individual Cry proteins, non-crystal forming insecticidal proteins, and synergistic interactions among Cry proteins and between Cry proteins and the spore. Thus, there are many components that determine the insecticidal potency of $B$. thuringiensis. While potency is critical, the success of a $B t$ bioinsecticide is also dependent on a number of other factors including crystal protein yield in fermentation, cost-of-production, handling properties of the formulated 
product, formulation components to improve foliar coverage and persistence, and product stability while in inventory. Of these, insecticidal potency and Cry protein yield and stability can be improved through genetic manipulation.

Currently registered $B$. thuringiensis products employ only a fraction of the known Cry proteins. The utility of many of these new proteins for insect control and the benefits of employing specific Cry protein compositions remains to be determined. Accordingly, there is little incentive to introduce foreign insecticidal genes into $B$. thuringiensis when so few of its native cry genes have been evaluated for commercial use.

Early attempts to improve $\mathrm{Bt}$ bioinsecticides relied on a conjugation-like process to transfer large cry plasmids from one strain to another. The utility of conjugal transfer is limited, however, because 1) the majority of crygenes cannot be readily transferred by this process, 2) specific cry gene combinations cannot be made, 3) cry genes modified for improved activity or stability cannot be exploited. Advances in molecular biology, the isolation of new crygenes, and a superficial understanding of Cry protein structure and function have together provided opportunities for improving $B t$ strains through more direct genetic manipulation.

\section{BIOINSECTICIDES BASED ON RECOMBINANT B. THURINGIENSIS STRAINS}

Three $B$. thuringiensis strains modified through recombinant DNA techniques have been registered as active ingredients with the U. S. EPA.: EG7673 (Raven $^{\mathrm{TM}}$ OF bioinsecticide), EG7841 (CRYMAX TM WDG/WP bioinsecticide), and EG7826 (Lepinox TM WDG/G bioinsecticide). In developing these genetically-modified Bts, Ecogen Inc. decided to take a conservative approach to facilitate timely regulatory approval and public acceptance: 1) The $B t$ strains are derived from isolates of the subspecies kurstaki, the same subspecies used in the production of DIPEL TM, Javelin ${ }^{\mathrm{TM}}$, and a host of other Bt products; 2) EG7673 and EG7826 are derivatives of the previously registered transconjugant Bt strains EG2424 and EG2348, respectively; 3 ) The cloned insecticidal genes introduced into these strains are derived from $B$. thuringiensis; and 4) An indigenous site-specific recombination system was use to delete all foreign DNA elements, including antibiotic resistance genes, from the recombinant cry plasmids after their introduction into $B t$, thus making the modified $B t s$ essentially non-transgenic (2).

EG7673 contains both a $c r y 3 B b$ and a cry3Aa gene and is a cost-effective producer of toxins active against Colorado potato beetle larvae. The lepidopteran-toxic EG7841 construct 11831 and EG7826 construct 11097 differ from EG7673 in that they contain cry genes modified for improved insecticidal activity. The cry1C gene in EG7841 construct 11831 contains a mutation that results in improved toxicity towards the beet armyworm, Spodoptera exigua. The cry1Ac/1F gene in EG7826 construct 11097 encodes a chimeric toxin with superior toxicity to the fall armyworm, $S$. frugiperda, when compared to the parental Cry1Ac and Cry1F toxins.

The Raven, CRYMAX, and Lepinox registration packages prepared for submission to the U. S. EPA. were no different than those required for naturally-occurring Bts. In all three cases, regulatory approval was obtained approximately one year after the date of submission.

These genetically-modified Bts, though not strictly transgenic organisms, provide an example of how a conservative approach to genetic manipulation can facilitate commercial application. For instance, it is not known what risks, if any, there are in the widespread application of recombinant microorganisms containing transmissible antibiotic resistance genes. Some commentators have insisted there are no significant risks, yet history is replete with examples of the unintended consequences of technology. For Ecogen, deletion of these unwanted DNA 
elements from commercial recombinant $B$ ts strains made good sense if only because it removed this issue from consideration. It is reasonable to conclude that this strategy contributed to the prompt regulatory approval of these recombinant Bts. Similarly, the use of native insecticidal genes was important: the cry $1 C$ variant in CRYMAX and the hybrid cry gene in Lepinox were readily approved because these genes, although modified by recombinant DNA techniques, are derived from $B$. thuringiensis cry genes. As a result, several unique bioinsecticide products have now entered the marketplace (3).

\section{A SAMPLING OF RESEARCH NEEDS AND ISSUES}

\begin{abstract}
Safety
Concerns have been raised about the safety of Bt-based bioinsecticides despite their long history of safe use. This pertains to Bts in general, recombinant or otherwise. For instance, the closely related species Bacillus cereus can cause food poisoning and at least some of the enterotoxin genes implicated in this pathology are reported to be present in B. thuringiensis. Similarly, a recent study suggested that an obscure subspecies of $B$. thuringiensis could act as an opportunistic pathogen in immunocompromised individuals. While this may be only guilt-by-association, it does suggest that there are rare instances where $B$. thuringiensis could be anything but harmless to humans. Finally, the presence of spores in most Bt bioinsecticide products has been cited as a possible health risk although little data has been presented to support this notion. How important are these concerns in light of the obvious benefits of Bt bioinsecticides and their long history of safe use?
\end{abstract}

\section{Insect resistance}

Insect resistance development will continue to be a concern, and not just because of the widespread cultivation of insect-resistant plants expressing cry genes. The diamondback moth, Plutella xylostella, has developed resistance to certain Cry1 proteins because of the extensive use of $B t$ bioinsecticides. Thus, there is an ongoing need to identify novel insecticidal proteins from $B$. thuringiensis as well as to evaluate the insecticidal properties of the many Cry proteins that have recently been described. Individual genes could be readily introduced into appropriate $B t$ host strains by recombinant DNA techniques and evaluated for efficacy.

\section{Use of novel insecticidal proteins}

As noted above, the majority of known $B t$ Cry proteins have not been utilized as active ingredients in bioinsecticide products. Certainly, some of these proteins, a number of which are phylogenetically distinct from the commonly used Cry proteins, will be deployed in bioinsecticide products or expressed in planta. This introduces a problem: the "long history of safe use" cited for $B$. thuringiensis actually relates to a small number of $B t$ strains producing a small fraction of the known crystal proteins. In the absence of any studies delineating their mode of action, to what extent should novel Cry proteins (or even Bt strains) be regarded as safe?

\section{Foreign genes}

Ultimately, the quest to improve bioinsecticides may lead to the introduction of foreign insecticidal genes into $B$. thuringiensis. Recent studies indicate that $B$. thuringiensis can transfer genetic information to other bacilli in soil and within the hoemocoel of infected insects (4). Obviously, some thought should be given to how this transfer could be limited, perhaps through the use of sporulation-deficient variants of $B$. thuringiensis. Aside from the issue of horizontal gene transfer, how should the regulatory requirements for a transgenic Bt differ from those of other recombinant Bts?

\section{REFERENCES}

1. Crickmore, N., Zeigler, D. R., Feitelson, J., Schnepf, E., Van Rie, J., Lereclus, D., Baum, J., and D. H. Dean. 1998. Revision of the nomenclature for the Bacillus thuringiensis pesticidal crystal proteins. Mol. Microbiol. Rev., in press. 
2. Baum, J. A.., Kakefuda, M., and C. Gawron-Burke. 1996. Engineering Bacillus thuringiensis bioinsecticides with an indigenous site-specific recombination system. Appl. Environ. Microbiol. 62:4367-4373.

3. Baum, J. A., Johnson, T. B., and B. C. Carl-ton. 1998. Bacillus thuringiensis: natural and recombinant bioinsecticide products, In: Methods in Biotechnology, Vol. 5: Biopesticides, Use and Delivery (F. R. Hall and J. Menn, Eds.), Humana Press Inc., Totowa, NJ., in press.
4. Vilas-Boas, G. F. L. T., Vilas-Boas, L. A., Lereclus, D., and O. M. N. Arantes. 1998. Bacillus thuringiensis conjugation under environmental conditions. FEMS Microbiol. Ecology 25:369-374. 